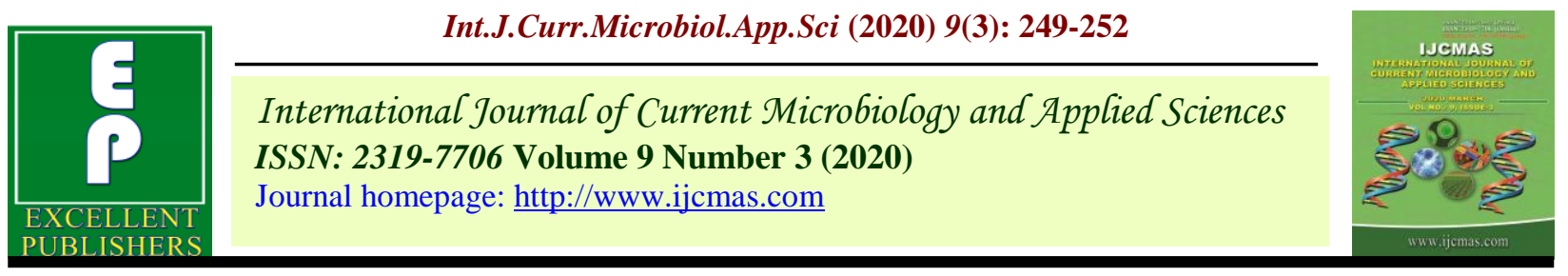

Original Research Article

https://doi.org/10.20546/ijcmas.2020.903.030

\title{
Gene Action and Heritability Studies for Seed Yield and its Components in Mungbean [Vigna radiata L.Wilczek]
}

\author{
S. R. Hange*, S. R. Shinde and V. S. Pawar \\ Department of Genetic and plant Breeding, Mahatma Phule Krishi Vidyapeeth, \\ Rahuri-413722 (M.S), India \\ *Corresponding author
}

\begin{tabular}{|l|}
\hline Key w or d s \\
Yield, Genes, Gene \\
Action, Heritability,
\end{tabular}

\section{A B S T R A C T}

In the present investigation a study was conducted to assess the nature and magnitude of yield attributing characters. The inheritance of the character viz; plant height and flower to pod ratio was controlled by additive gene action. The rest of the nine characters under the control of non additive gene action therefore the heterosis breeding is recommended to exploit the benefit of hybrid vigor. Heritability is good index of the transmission of character from parents to their offspring. The yield contributing characters Viz. plant height (56.07), branches per plant (39.91), including grain yield (39.72) per plant had exhibited moderate level of involvement of genes to control the transmission of the character. The features like days to maturity (32.25), flower to pod ratio (48.82), percent flower drop (34.73), and protein percent (36.85) had expressed similar trend of narrow sense heritability. While the character like days to 50 percent flowering (13.19), pods per plant (12.22), 100 seed weight (8.66) and seeds per pod (17.04percent) had shown the transmission of the characters under the large influence of different environmental factors.

\section{Introduction}

Mungbean is an important pulse crop. It is considered to be the hardiest among the pulse crops. India is prime mungbean producer, contributing about 75 per cent of the world production. The major mungbean producing states are Andhra Pradesh, Maharashtra, Gujarat, Orissa and Tamilnadu. Line $\times$ tester cross is a modified form of the top-cross proposed by Davis in 1927 for inbred evaluation. The line $\times$ tester technique was developed by Kempthorne in 1957. The success of most crop improvement programs largely depends upon the genetic variability and the heritability of desirable traits.

The magnitude and type of genetic variability helps the breeders to determine the selection criteria and breeding schemes to be used for improvement purposes. For any planned mungbean breeding program to improve seed 
yield potential through important parameters of crops, it is necessary to obtain adequate information on the magnitude and type of genetic variability and their corresponding heritability. Heritability indicates the relative degree of a character transmitted from parents to progeny. The study further stated that a high genetic advance accompanied with high heritability estimates offered a most effective criterion of selection from segregating.

\section{Materials and Methods}

The present study was undertaken on Line $x$ Tester analysis in which set of 18 different crosses, 9 inbred lines, comprising 6 females and 3 males and 1 check were used. The inbred lines were collected from the Principal Scientist, Pulses Improvement Project M.P.K.V., Rahuri; Genotype possessing diversity for yield and other component were selected.

Five random plants from each treatment in each replication were selected for recording observations. The selected plants were tagged at the age of 30 days. The observations on five randomly selected plants in each replication was recorded for twelve characters viz; days to 50 per cent flowering, days to maturity, plant height, branches per plant, pods per plant, 100 seeds weight (g), grain yield per plant $(\mathrm{g})$, seeds per pod, flower to pod ratio percent, percent number of flower dropped, protein content (percent) and pod shattering.

\section{Results and Discussion}

\section{Gene action}

The value of the estimates of GCA and SCA variance, their A: D ratios and percentages of the heritability in narrow sense are presented in Table 1. The variance due to GCA effects were higher for pods per plant, plant height (cm), flower to pod ratio, grain yield per plant, number of flower dropped, while the values of variance due to SCA effects were higher for pods per plant, plant height $(\mathrm{cm})$, flower to pod ratio, grain yield per plant, percent flower drop, than the rest of the characters.

While comprising the GCA and SCA variance for individual character, the value of SCA variance were higher than those of GCA variance for all the characters except plant height, flower to pod ratio. Estimated dominance variance was higher than the additive variance (G2 A) for all characters except plant height, flower to pod ratio.

The A: D ratio was lesser than the unity for these characters indicating predominance of non-additive gene action. The A:D ratio was greater than the unity for plant height and flower to pod ratio, indicating predominance of additive gene actions.

\section{Heritability}

The result estimated that out of the twelve character studied the value of heritability were moderate for plant height (56.07), flower to pod ratio (48.82), grain yield per plant (39.72), protein percent (36.85), number of flower dropped (34.73) and days to maturity (32.25), While value of the rest of the characters between 8.66 to $17.04 \%$ which were low.

Percentage contribution of females, males and females $x$ males interaction to the hybrid sum of square

Percentage contribution of males, females and females $x$ males to the sum of square of hybrids are presented in Table 2. The contribution of female parents was ranged between $7.07 \%$ (seeds per pod) to $72.14 \%$ (plant height). 
Table.1 Gene action and heritability for eleven different characters in Green gram

\begin{tabular}{|c|c|c|c|c|c|c|c|c|c|c|c|}
\hline Parameter & $\begin{array}{c}\text { Days to } \\
50 \% \\
\text { flowering } \\
\text { (Days) }\end{array}$ & $\begin{array}{l}\text { Days to } \\
\text { Maturity } \\
\text { (Days) }\end{array}$ & $\begin{array}{c}\text { Plant } \\
\text { height } \\
\text { (cm) }\end{array}$ & $\begin{array}{l}\text { Branches } \\
\text { per plant } \\
\text { (number) }\end{array}$ & $\begin{array}{c}\text { Pods per } \\
\text { Plant } \\
\text { (number) }\end{array}$ & $\begin{array}{c}100 \\
\text { Seeds } \\
\text { Weight } \\
\text { (g) }\end{array}$ & $\begin{array}{c}\text { Grain } \\
\text { yield } \\
\text { per } \\
\text { plant (g) }\end{array}$ & $\begin{array}{l}\text { Seeds per } \\
\text { Pod } \\
\text { (number) }\end{array}$ & $\begin{array}{c}\text { Flower } \\
\text { to pod } \\
\text { ratio } \\
(\%)\end{array}$ & $\begin{array}{c}\text { Percent } \\
\text { flower } \\
\text { drop } \\
(\%)\end{array}$ & $\begin{array}{c}\text { Protein } \\
\text { content } \\
(\%)\end{array}$ \\
\hline$\delta^{2}$ gca & 0.04 & 0.42 & 94.01 & 0.14 & 11512.82 & 0.02 & 17.94 & 0.07 & 29.29 & 12.39 & 1.23 \\
\hline$\delta^{2}$ sca & 0.14 & 0.76 & 67.77 & 0.17 & 21251.62 & 0.08 & 24.41 & 0.19 & 27.69 & 18.16 & 1.96 \\
\hline$\delta^{2 A}$ & 0.04 & 0.42 & 94.01 & 0.14 & 11512.82 & 0.02 & 17.94 & 0.07 & 29.29 & 12.39 & 1.23 \\
\hline$\delta^{2 D}$ & 0.14 & 0.76 & 67.77 & 0.17 & 27251.62 & 0.08 & 24.41 & 0.19 & 27.69 & 18.12 & 1.97 \\
\hline$\delta^{2 E}$ & 0.14 & 0.13 & 5.87 & 0.03 & 55382.40 & 0.05 & 2.81 & 0.12 & 3.02 & 5.18 & 0.15 \\
\hline $\mathbf{h}^{2}(\mathrm{~ns}) \quad \%$ & 13.19 & 32.25 & 56.07 & 39.91 & 12.22 & 8.66 & 39.72 & 17.04 & 48.82 & 34.73 & 36.85 \\
\hline$\delta^{2}$ g.c.a/ $\delta^{2}$ s.c.a & 0.30 & 0.56 & 1.38 & 0.81 & 0.42 & 0.15 & 0.73 & 0.33 & 1.06 & 0.68 & 0.62 \\
\hline $\begin{array}{c}\text { Nature of gene } \\
\text { action }\end{array}$ & $\begin{array}{c}\text { Non- } \\
\text { additive }\end{array}$ & Non-additive & Additive & Non-additive & Non-additive & $\begin{array}{c}\text { Non- } \\
\text { additive }\end{array}$ & $\begin{array}{c}\text { Non- } \\
\text { additive }\end{array}$ & $\begin{array}{c}\text { Non- } \\
\text { additive }\end{array}$ & Additive & $\begin{array}{c}\text { Non- } \\
\text { additive }\end{array}$ & $\begin{array}{c}\text { Non- } \\
\text { additive }\end{array}$ \\
\hline
\end{tabular}

Table.2 Percentage contributions of females, males and females x male interaction to sum of square of hybrids

\begin{tabular}{|c|c|c|c|c|}
\hline Sr. No. & Characters & Females (\%) & Males (\%) & Hybrid \\
\hline $\mathbf{1}$ & Days to 50 percent flowering & 44.44 & 0.69 & 54.86 \\
\hline $\mathbf{2}$ & Days to maturity & 47.49 & 4.44 & 48.06 \\
\hline $\mathbf{3}$ & Plant height (cm) & 72.14 & 1.84 & 26.004 \\
\hline $\mathbf{4}$ & Branches per plant & 60.61 & 1.29 & 38.09 \\
\hline $\mathbf{5}$ & Pods per plant & 28.12 & 12.22 & 59.65 \\
\hline $\mathbf{6}$ & 100 seeds weight (g) & 31.08 & 3.50 & 65.40 \\
\hline $\mathbf{7}$ & Grain yield per plant & 54.66 & 4.21 & 41.11 \\
\hline $\mathbf{8}$ & Seeds per pod & 7.07 & 21.27 & 71.65 \\
\hline $\mathbf{9}$ & Flower to pod ratio (\%) & 67.15 & 1.38 & 31.45 \\
\hline $\mathbf{1 0}$ & Percent flower drop & 43.13 & 9.59 & 47.27 \\
\hline $\mathbf{1 1}$ & Protein (\%) & 48.83 & 5.64 & 45.51 \\
\hline $\mathbf{1 2}$ & Pod shattering & Nil & Nil & Nil \\
\hline
\end{tabular}


The contribution of males parents was ranged from $0.69 \%$ (days to $50 \%$ flowering) to $21.27 \%$ (seeds per pod). The percentages of contribution by female parent to the hybrids were higher for all the characters than those by male parents. The contribution due females $\mathrm{x}$ males was ranged between $26.00 \%$ (plant height) to $71.65 \%$ (seeds per plant percent).

\section{References}

Ayyangouda Patil and Kajjidoni, S, T., 2005, Gene action for morpho - physiological traits in green gram [Vigna radiata $(\mathrm{L}$.) Wilczeck]. National J. Pl. Improv., 7 (1): 15-17. combinations. J. Amer. Soc. Agron. 24: 523-534.

Comstock, R. F. and Robinson, H. F., 1962, Estimation of average dominance of genes. In: Heterosis, ed., J. W. Gowen, Ch. 30 Iowa State College Posess. America.

Gawande, V. L and Patil, J. V ., 2005, Gene action for seed yield and its components in mungbean [Vigna radiata (L.) Wilczek]. J. Maharastra Agric. Univ., 30 (3): 285-288.

Godhani, P. R., Jaisani, B. G., and Patel, G. J.,
1978, Epistatic and other genetic variances in green gram varieties. Gujarat Agric. Univ Res. J., 4: 1-6.

Hayman, B. I., 1958, Separation of epistatis from additive and dominance variation in generation means. Heredity, 12: 371391.

Jinks, J. L. and Perkins, J. M. and Breese, E. L., 1969, A general method of detecting additive, dominance epistatic variation for metrical traits. II. Application to inbred lines. Heredity, 24: 45-57.

Jinks, J. L. and Perkins, J. M., 1972, A general method of detecting additive, dominance epistatic component of variations, III, $F_{2}$ and back cross population. Heredity, 25: 419-422.

Kearsey, M. J. and Jinks, J. L., 1968, A general method of detecting additive, dominance and epistatic variation for metric traits I Theroy. Heredity, 23: 403-409.

Singh, K. B and Malhotra, R. S., 1970, Estimation of genetic and environmental variability in mung bean (Phaseolus aureus Roxb.), Madras Agric. J., 57: 155-159.

\section{How to cite this article:}

Hange, S. R., S. R. Shinde and V. S. Pawar. 2020. Gene Action and Heritability Studies for Seed Yield and its Components in Mungbean [Vigna radiata L. Wilczek]. Int.J.Curr.Microbiol.App.Sci. 9(03): 249-252. doi: https://doi.org/10.20546/ijcmas.2020.903.030 